\title{
Increasing Of Geometry Learning Outcomes Using Savi Method With Fifth Grade
}

\author{
Defrina Martha Widyawati ${ }^{1 *}$, Stefanus C Relmasira² ${ }^{2}$, Janelle L. Juneau ${ }^{3}$ \\ 1,2,3 Jurusan Pendidikan Guru Sekolah Dasar (PGSD), FKIP Universitas Kristen Satya Wacana, Indonesia.
}

\author{
A R T I C L E I N F O \\ Article history: \\ Received 22 August 2018 \\ Received in revised form \\ 10 September 2018 \\ Accepted 16 October 2018 \\ Available online 29 \\ November 2018

\section{Keywords:} \\ SAVI, Mathematics, \\ Learning Outcomes, Cycle 1, \\ Cycle 2
}

\begin{abstract}
A B S T R A C T
The purposes of this research are to know if the implementation of SAVI method is able to increase the mathematics learning outcomes at SD Negeri Gedangan 01 Tuntang and describing the implementation of SAVI Method. This research type is collaboration classroom action research. The subject of this research is the fifth grade of SD Negeri Gedangan 01 Tuntang consists of 21 students. The research instruments used to collect the data are observation sheets and evaluation test that analyzed by quantitatively. The result shows academic achievement increase to $33 \%$ from the pre-cycle to cycle one. In cycle two, the score was significantly increased to $48 \%$. The reason why researcher used the SAVI method is because it focuses on the all sense of students that used in the learning process. Researcher used video interactive, some picture, some activities such as arranged the puzzle and tangram; make the solid geometry from the wood lighter and this activity made students to use their all sense. The condition of the teaching and learning process had been conducive and enthusiast from the all students in grades five. Students have many types of learning style like visual, audio, kinesthetic, and tactile. Thus, when SAVI was implemented students got the chance to learn well in the teaching and learning process.
\end{abstract}




\section{Introduction}

Mathematics learning standards, according to Van De Walle (1994), says that the teacher should encourage and accept the use of the computer or other technology. According to Tyas (2014), the learning model of SAVI (Somatic, Audio, Visual, Intellectual) is one of many learning models that use kinesthetic learning of the senses to develop skill, processing and improves the learning outcome. The elements of SAVI are Somatic, Audio, Visual and Intellectual. Somatic element is where students learn by doing so the students can draw or make geometry using paper. Audio element is learning aurally so if the teacher uses video that has sound, they can record the explanation and the students can remember it. Visual element is learning by watching such as the students can watch a video using the LCD projector. Intellectual element is learning by solving a problem, for example, discussion and brainstorming possible solutions then experiment to find which works best. The teacher must pay attention to the method of teaching in mathematics class so teachers can combine the materials and the tools to support the learning process. The technology, especially modern media is one of the tools that can help the teacher to effectively use the method and apply it in the classroom.

There are five principles that are classified for affective learning. According to Sani (2014) the principles are: a) Integrated, learning will be effective if the students are integrating the knowledge or skills acquired in daily life; b) Activation, learning will be effective if the students are activating their prior knowledge to connect the new knowledge; c) Application, learning will be effective if the students are applying the knowledge or skills acquired in daily life; d) Demonstration, learning will be effective if the students are seeing the demonstration of skills that will be learned; e) According to the needs, learning will be effective if the students need the knowledge and skills when they practice it. These principles show if the teachers' role is needed to create effective learning. Teachers must make the topic that the students learn connect within daily life and students can use it to solve the problems with the topic or materials that already learned before so teachers also pay attention the topic that the students need. In addition, teachers also make the learning process be of interest so it will elicit the students activly in the classroom. Students' enthusiasm in the learning process and creates a desire to learn and a feeling of needing to learn.

To help the teachers know the type of learning, here are a few guidelines on identifying student learning types through character recognition and its nature according to Kesuma (2010) are (a) Visual is for students who sets type is visual in which eyes or visual sightplay an important role. In this case, the teaching method used by the teacher should be focus more on a show or media; (b) Audio is the type that relies on learning through ears (hearing devices) for that then the teacher should pay attention to the students hearing instrument; (c) Kinesthetic style students always responds lessons received with physical activity. Students will learn were by physical motion or using fingers and hands while studying; (d) Tactile means touch; this type requires the individual learn well by touching that provides information easier for them to remember; (e) Olfactory learning style students are thosehave a dependence on smell. Students like this will very quickly adjust to the atmosphere of the smell of the environment; (f) Gustative are the students are more quickly understand what is learned through the sense of taste; (g) A combination is the learners who have the ability to follow the lesson by using more than one sense; they can receive eye and ear lessons at once while learning.

The approach to accomplish SAVI combines physical movement with intellectual activity and uses all fives senses to influence learning. As for the elements of SAVI according to Muchyidin \& Kusniya (2012), among others: somatic is learning with the move and do, students can movement of the body (hands-on, physical activity) where how to learn by experiencing and doing; auditory is learning with speech and hearing through listening the information, speaking with presentation, argumentation, suggested and responding to; visual is learning by observing, use eye senses through observing, drawing, demonstrating, read, use media and props; intellectuals is learned by solving problems and thinking that learning must be using the ability of thinking (minds-on), learning must be with the concentration of the mind to practice using it through rationality, investigate, identify, find, create, construct, solve problems, and apply. SAVI is the method to maximize using all senses.

The stages that need to be taken in the SAVI are preparation, delivery, training, and the appearance of results. Any creations, teachers need to be prepared well in all four stages. According to Kurnianti (2016), as follow : Preparation Phase (Activities Of Introduction), Stage Of Delivery (Core Activities, Training Stage (Core Activities). Stage Appearance Results (Stage Cover)

Thus, from the descriptions mentioned above the researcher decided to conduct action research (classroom action research) about "Increasing Geometry Learning Outcomes using SAVI Method with Fifth Grade First Semester Students at SD Negeri Gedangan 01 Tuntang, Semarang 2018/2019”. 


\section{Methods}

This classroom action research is in fifth-grade students of SD Negeri Gedangan 01 Tuntang located in Semarang. The located is on Jalan Haji Thoyib Soebadi Km. 4 Gedangan Kec. Tuntang Kab. Semarang. The implementation of this research was done in the first semester of academic year 2018/2019. The subject of this research is the fifth grade of SD Negeri Gedangan 01 Tuntang. The number of students in the class is 21 students who are made up of 11 male students and 10 female students. The fifth-grade homeroom teacher at the moment is Ibu Puji RahayuniS.Pd. SD and School Principal is Ibu Tutiningsih S.Pd.

This research type is collaboration classroom action research; according to Slameto (2015) classroom action research is effective research to improving the learning process in the classroom and as teachers' effort in an action to improve the quality of the learning process. This research is used to find the problems or difficulty that happened in the learning process and find the solutions to improve the teaching and learning style on next learning process. The action is done by teachers and the students with the guidance and direction of teachers and principal. The effort which is the researcher chose is being a focus at cognitive learning outcomes using SAVI (Somatic, Auditory, Visual and Intellectual) method.

According to Slameto (2015), the independent variable is variable which is as a cause the other variable and as usual, the researcher is manipulating, observe and measure to know the influence for the other variable. The SAVI learning model is an independent variable which is learning that using all the senses of students, students learning the process with physical movement and intellectual activities and give the freedom for the students who aware with their learning model is different said Rofiah (2015). Students are learning by doing so students must listen, speak, give the opinion, use the learning tools and also be able to concentrate thinking logically, identify the problems, find, create, problem solve and implement.

According to Slameto (2015), the dependent variable is variable which is become a result of the effect of independent variable such as observe and assess. In this research, the dependent variable is the result of mathematics learning of fifth-grade students of SD Negeri Gedangan 01. The learning outcomes are the result of students got after the learning process and the score or number as a success rate. The success rate is the test score minimum of the test with the objectives of mathematics learning that have been determined.

At the stages, the researcher takes the students' learning outcomes from pretest from the mathematics materials, which is not already taught by the homeroom teacher. Then from the results, the researcher analyzed the materials that students know or not before and prepare the materials which teacher preparation in the next meeting in cycle one.

The researcher can reflect on teaching and learning activities using the observation sheet. The researcher will find the weakness when they teaching in the classroom. Based on the weakness, the researcher can make the other planning to improve the ways in teaching and learning process in cycle two.

Based on the reflection, the researcher will reflect on their teaching process in the classroom. The researcher will find the weakness and the advantages of the method that they apply in the classroom. After that, the researcher and the homeroom teacher will discuss the result of the teaching process. If the method is a success in the classroom, it will help the teacher to apply SAVI in the classroom at the next meeting. When the students are also successful in the indicators, it will be clear and complete in cycle two.

Validity analysis in this research will be used with SPSS 16.0 for windows program. Based on SPSS 16.0 for windows output analysis, to find out the correlation index between grain value and total value can be seen in Output Item Total Statistics in column Corrected Item-Total Correlation. If Corrected Item-Total Correlation> 0.456 it can be concluded that all items of the instrument are said to be valid. Based on the table $r$, we get 12 valid questions in cycle 1 of 30 tested questions, and in cycle 2 there are 22 valid questions from 30 tested questions, and used as test instrument by the researcher to know the student learning result. The following items are declared valid and invalid.

Based on the output analysis of the SPSS 16.0 for windows program, the $\mathrm{N}$ of Items column shows the number of corresponding item numbers. While the Cronbach's Alpha reliability index of 0.874 . Since the Alpha reliability index range value as described above reaches a value of 0.80 to 1.00 it can be concluded that the instrument used in Cycle 2 is very reliable.

Analysis of the level of difficult questions is used to know how big the difficult of the question. According to Wardani et, all (2012) said if the level of difficulty is a number that shows the proportion of the students who answered a point. The greater of the level of difficulty questions means the questions are easier; in addition, the lower of the level of difficulty questions means the questions are more difficult. The 
level of difficult questions is to correctly answer that usually expressed by the index. The formula to count the level of difficult questions as below:

$$
\mathrm{P}=\frac{B}{N}
$$

Explanation:

$\mathrm{P}=$ the proportion of student who answered correctly

$B=$ Number of student who answered correctly

$\mathrm{N}=$ Total of student

To determine the difficulty level of the item can use the difficulty level table, as follows.

Tabel 1. Level of Difficulty Score Range

\begin{tabular}{cc}
\hline Score Range & Level of Difficulty \\
\hline $0.00-0.25$ & Difficult \\
$0.26-0.75$ & Moderate \\
$0.76-1.00$ & Easy \\
\hline
\end{tabular}

The indicators of success in this research can be seen on how to reach the indicators of the success of using the SAVI method in mathematics' learning process. The researcher can use the observation sheet that the observer fill during the SAVI method going on and the result is to fulfill the steps of the learning process of SAVI. In addition, the indicators of success in this research is determined by Kriteria Ketuntasan Minimum (KKM) to be achieved by students is 70, while the students that get the minimum score is $75 \%$ from the total students in the classroom and also the average of active students in the learning process is $75 \%$ of the total students.

\section{Research Result and Discussion}

Based on the result of the observation in cycle two have been implemented Somatic, Auditory, Visualization and Intellectual (SAVI) method in the mathematics lesson. The researcher did reflection with the homeroom teacher and it has advantages for students. Students were being interested in the manipulative tools and being active when followed the lesson. Students trained to express their imagination, prior knowledge, and their experience to think and to connect with the lesson. Somatic, Auditory, Visualization, and Intellectual (SAVI) method learning stage is running well and the learning media is better because students interest with the media used. The learning outcomes are increasing from pre-cycle to cycle one and cycle two, where students complete score of 4 students (19\%), in cycle one increased to $11(52 \%)$ and significantly increased on the cycle two with the total number of all students that the number is $21(100 \%)$. Students' learning outcomes were complete because the result is increased and achieved the indicators. So there is no need for another cycle.

The disadvantage is sometimes students can't control if they discussed in the group and doing activities outside the classroom. Because some students have different learning style, sometimes the students who have one learning style will disturb with the other learning style and teacher must control the classroom.

In the table can be seen that increasing the students learning outcomes are complete the KKM (70) in each cycle. 4 students are reached the KKM in pre-cycle, it shows the 21 students can't reach the KKM and the students didn't understand the lesson yet. In cycle one, 11 students already reached the KKM, it shows the percentage of students who reach the KKM had increase that is $33 \%$ from the pre-cycle to cycle one. In cycle two, the score is through significant increase because all of the students already got the score that passes over the KKM, namely 21 students. It gives the comparison between pre-cycle and cycle one is $33 \%$, cycle one and cycle two is $48 \%$.

At the beginning of the research, the observation's result in the SD Negeri Gedangan 01 Tuntang showed if the method that teacher used in the teaching and learning process had still teacher centered or conventional. It means the communication only one way in the classroom, the teacher being an information center rather than the students being the communication object. This school already has the facility for teaching and learning process such as LCD projector, laptop but the digital tools that available 
in the school is not balanced with the ability and readiness of human resources in the school and the teacher appetence to use the digital tools.

That's influence on the students understanding about the lesson and the type of students learning that monotone. It could show from the learning outcome of pre-cycle, there only 4 students who reach the KKM. Based on before the research which is the researcher used observation method to get the result of students, the researcher asked students to draw the plane geometry from their observation around the school. In this cycle, 11 students were reached the KKM.

This experienced gave suggestion to the researcher. The researcher would use Somatic, Auditory, Visualization, and Intellectual (SAVI) method. The reason why the researcher used the Somatic, Auditory, Visualization, and Intellectual (SAVI) method is this method focused on all sense of students that used in the learning process. The researcher used video interactive, some picture of plane geometry; some activities that connect with the lesson such as arranged the puzzle and tangram; make the solid geometry from the wood lighter and this activity made students use their all sense. The condition of the teaching and learning process had been conducive and enthusiast from all students in grades five. Students had any type of learning like visual, audio, kinesthetic, and tactile got the chance to learn well in the teaching and learning process. The result of the research showed if used SAVI method, all of the students reached the KKM.

\section{Conclusion and Recommendation}

The result of the research showed if the researcher found out the fact before the research, the method in the teaching and learning process was teacher-centered that have the weakness. That made the condition in the classroom too monotonous because of the communication is only one way, teacher as active and students as passive. It influenced the achievement of the process in the learning process, especially in the plane geometry of mathematics. Before the research, the students have low enterprise and only 4 students who reached the KKM. In cycle one when the researcher used the picture with the observation approach, students had been active in the lesson process and 11 students who reached the KKM. To follow up the result, the researcher used Somatic, Auditory, Visualization, and Intellectual (SAVI) method with many learning media like video, puzzle, tangram, and solid geometry. Finally, all of the students are active in the teaching and learning process and reach the KKM.

The recommendations will usefully if it gives advantages for people. Especially: a) For Schools; from the result of this observation so it gives feedback for the school to more give attention to developing the ability of the teacher to prepare the media and learning method, b) For Teachers; this research can be evaluation object and enrichment to prepare the lesson and implementing the active learning process, creative and innovative for achievement the learning objectives and the target of KKM that already be appointed, c) For Researchers; the result of the research can be a suggestion to the researcher when in the classroom future and works as a professional teacher.

\section{References}

Kesuma, U. P. (2010, September 3). Mengenal Berbagai Tipe Belajar Siswa. Dipetik April 19, 2018, dari Bisnis Guru: http://bisnisguru.blogspot.com/2010/03/mengenal-berbagai-tipe-belajarsiswa_09.html

Kurnianti, S. (2016). Model Pembelajaran SAVI. Dipetik July 30, 2018, dari Repository: http://repository.ump.ac.id/943/3/BAB\%20II_SUSI\%20KURNIANTI_MATEMATIKA\%2716.pdf

Muchyidin, A., \& Kusniya. (2012). Pengaruh Penerapan Model Pembelajaran Savi(Somatic, Auditory, Visual, And Intellectual)Terhadap Kemampuan Berpikir Geometri Siswa. Dipetik July 30, 2018, Dari Academia.Edu:

Http://Www.Academia.Edu/27967999/Pengaruh_Penerapan_Model_Pembelajaran_Savi_Somatic_A uditory_Visual_And_Intellectual_Terhadap_Kemampuan_Berpikir_Geometri_Siswa_Studi_Eksperime ntal_Terhadap_Siswa_Kelas_VII_SMP_Negeri_1_Gegesik_Cirebon_Pada_Pokok_Bahasan_Ba

Rofiah, F. (2015, April 07). Pengertian Pendekatan SAVI. Dipetik August 08, 2018, dari EUREKA PENDIDIKAN: https://www.eurekapendidikan.com/2015/04/pendekatan-pembelajaran-savisomatis.html

Sani, R. A. (2014). Inovasi Pembelajaran. Jakarta: PT Bumi Aksara. BIBLIOGRAPHY \l 1057 
Slameto. (2015). Metodologi Penelitian dan Inovasi Pendidikan. Salatiga: Satya Wacana University Press.

Tyas, E. N. (2014). Peningkatan Keterampilan Proses Dan Hasil Belajar Subtema Tugasku Sehari-Hari Di Rumah Menggunakan Model Pembelajaran Savi Pada Siswa Kelas Ii Sdn 1 Bolo. Scholaria: Ejournal UKSW, 69-70.

Van De Walle, J. A. (1994). Elementary School Mathematics: Teaching Developmentally. Second Edition. New York: Longman.

Wardani, N. S., \& all, e. (2012). Asesmen Pembelajaran SD. Salatiga: Widya Sari Press Salatiga. 